
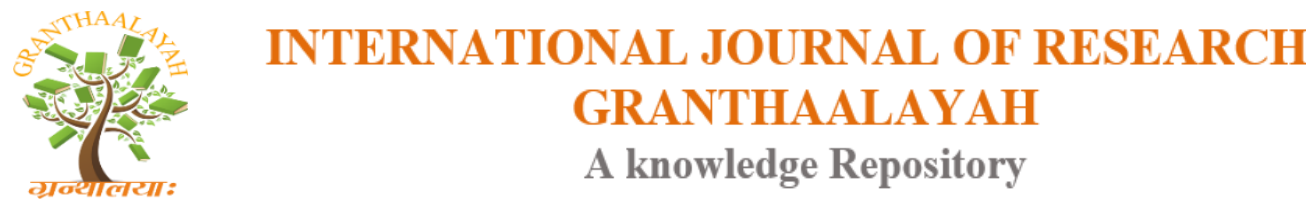

Science

\title{
DELTAIC AND SHELF DEPOSITIONAL PACKAGES OF THE GULANI MEMBER OF PINDIGA FORMATION, GONGOLA SUB-BASIN, NORTHERN BENUE TROUGH, N.E. NIGERIA
}

\author{
B. Shettima ${ }^{1}$, A.I. Goro², M. Bukar' ${ }^{1}$, Y.B. Mohammed ${ }^{1}$ \\ ${ }^{1}$ Department of Geology, University of Maiduguri, Borno State, Nigeria \\ ${ }^{2}$ Department of Geology, FUT Minna, Niger State, Nigeria
}

\begin{abstract}
Stratigraphic and facies analysis of the Gulani Member of the Pindiga Formation in the Gongola Sub-basin of the Northern Benue Trough indicated that the lithostratigraphic architecture of the formation are characterized by three bioturbated lithologic units. These includes the lower succession of heterolithic units with fine grained sandstones and mudstone interbeds, passing into succession of medium-coarse grained sandstone with dominantly trough crossbeds and a upper succession of medium grained trough crossbedded sandstone and mudstone interbeds. Facies evaluation of these distinct succession indicated development of a corresponding pro-delta sands and clays, moving into delta front sands and then shelf sandstone and claystone respectively. Thus suggesting that the Gulani Member was generally formed in a coastal setting defined by river dominated deltaic setting and shelf depositional environment.
\end{abstract}

Keywords: Gongola Sub-Basin; Gulani Member; Deba Fulani Member; Bioturbated.

Cite This Article: B. Shettima, A.I. Goro, M. Bukar, and Y.B. Mohammed. (2018). "DELTAIC AND SHELF DEPOSITIONAL PACKAGES OF THE GULANI MEMBER OF PINDIGA FORMATION, GONGOLA SUB-BASIN, NORTHERN BENUE TROUGH, N.E. NIGERIA." International Journal of Research - Granthaalayah, 6(4), 188-197. https://doi.org/10.29121/granthaalayah.v6.i4.2018.1643.

\section{Introduction}

The Turonian of the Gongola Sub-basin of the Northern Benue Trough (Fig.1) of Nigeria is marked by a regressive phase pre-dating the mid-Cretaceous global transgressive event. These regressive sandstone units are product of complex interactions of seawards processes of waves, tides and storms, and landward fluvial activity, building out several coastal environments along shorelines. These regressive units are represented in the Gongola Sub-basin by the Dumbulwa, Deba-Fulani and Gulani Members of the Pindiga Formation. They are generally laterally equivalent and conformably overlying the transgressive shales and limestone sequences (Fig.2), and the Gulani Member which is the focus of this research is generally restricted to the eastern margin of the subbasin. Stratigraphically, the formation is partitioned into three parts with upper part consisting of 
granulestone to coarse grained sandstones associated with mudstone partings. The middle part has fine to medium grained sandstones intercalated with siltstones and shelly limestones, whereas the lower part is characterized by thin sandstones, siltstones and thicker calcareous sandstones [1]. Previous studies on this formation are generally skewed towards its stratigraphy, paleontology and chronology [1-3]. Therefore, this research aims to evaluate its facies attributes and their systematic association so as to establish the depositional environments within which it evolved.

\section{Geological and Statigraphic Setting}

The Benue Trough of Nigeria is a rift basin in the Central West Africa that extends NNE-SSW for about $1000 \mathrm{~km}$ in length and 50-150 km in width [4,5]. The southern limit is the northern boundary of the Niger Delta, while the northern limit is at the Dubulawa-Bage High, which marks the southern boundary of the Chad Basin (Fig.1) [1]. The Benue Trough is geographically subdivided into Northern, Central and Southern Benue Trough (Fig.1). The Northern Benue Trough is made up of three arms: the N-S striking Gongola Arm, E-W striking Yola Arm and the NE-SW striking Muri-Lau Arm [4] (Fig.2). The Trough is over 6000m deep containing Cretaceous to Tertiary sediments of which those predating the mid-Santonian have been tectonically deformed, to form major faults and fold systems across the basin.

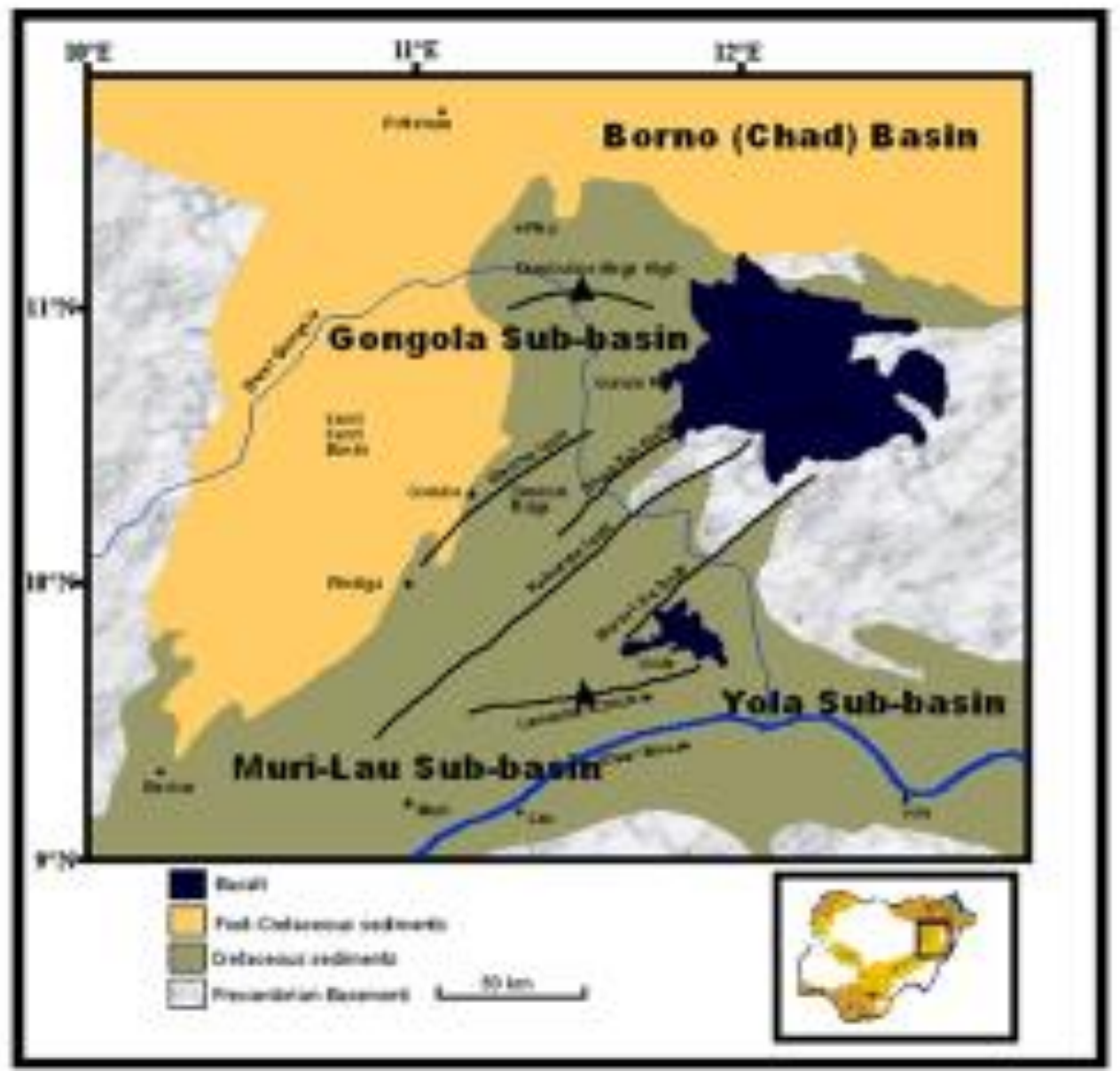

Figure 1: Geological map of Northern Benue Trough (modified from Zaborski et al, 1997). 


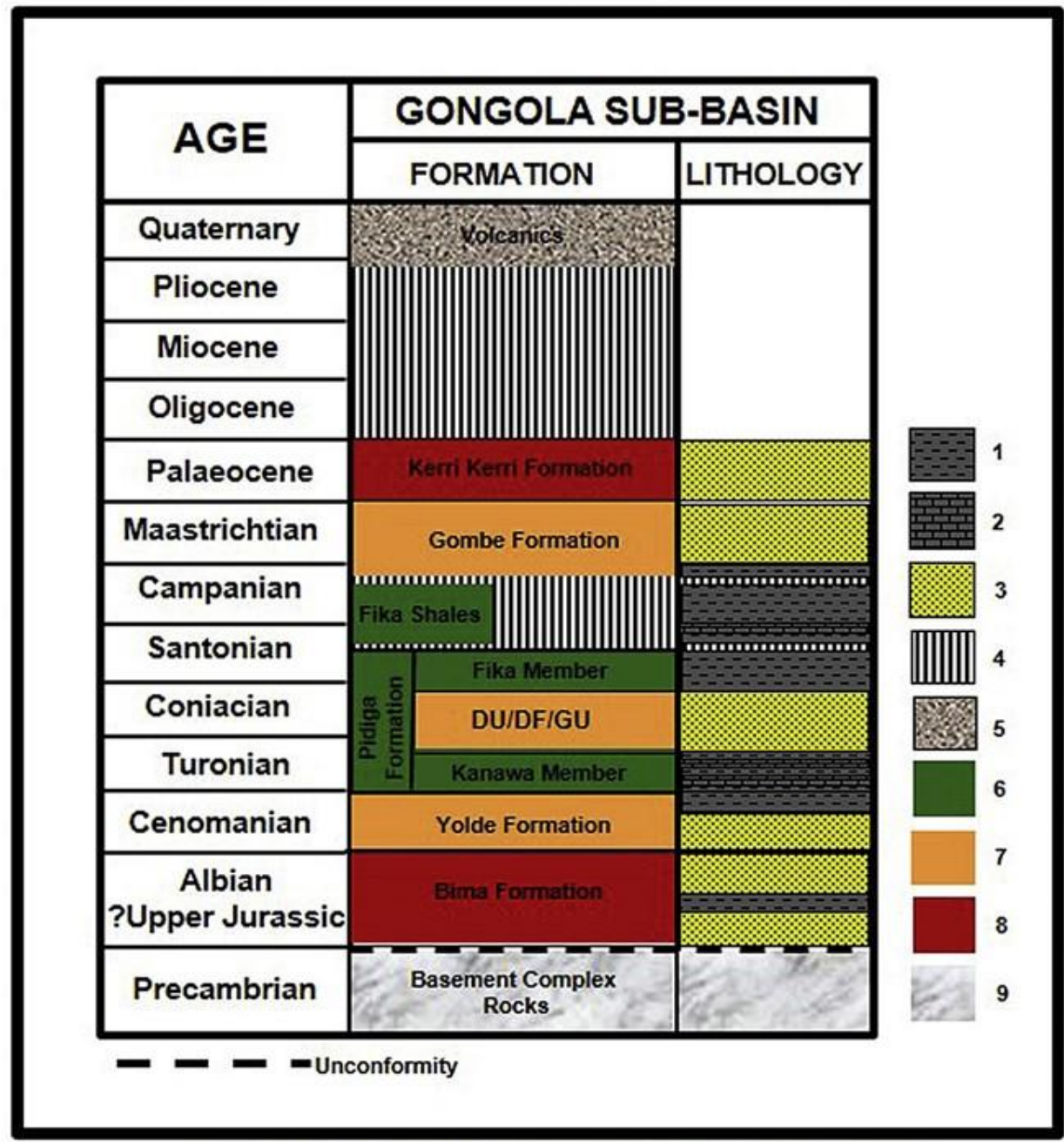

Figure 2: Showing the stratigraphy of the Gongola sub-basin (modified from [1]. 1-Mudstone, 2Limestone, 3-Sandstone, 4-Hiatus, 5-Basalt, 6-Marine sediments, 7-Transitional marine sediment, 8-Continental sediments, 9-Basement complex (DU- Dumbulwa Member).

In the Gongola Sub-basin, the (Aptian-Albian) continental Bima Formation represents the basal part of the sedimentary succession. It unconformably overlies the Precambrian Basement Complex and consists of three siliciclastic members: the lower Bima (B1), middle Bima (B2) and upper Bima (B3). Its lithology and depositional environments have been discussed by [3, 6, 7, 8] (Fig.2). The Cenomanian Yolde Formation conformably follows and represents the onset of marine incursion into the basin $[9,10]$. The Turonian-Campanian recorded full marine transgression associated incessant regressive phases leading to the deposition of the Pindiga Formation [1, 11]. Pindiga Formation consist five lithostratigraphic members: the Kanawa Member which is the basal member comprises of limestone and shale intercalations, the Gulani Member, the Deban-Fulani Member, the Dumbulwa Member and the Fika Member which is the top most Member consisting of shale and very few limestones [1]. The estuarine/deltaic Gombe Formation of Maastrichtian age [2] overlies the Pindiga Formation and it represents the youngest Cretaceous sediment in the Gongola Sub-basin. The Kerri Kerri Formation of Paleocene age accounts for the only record of Tertiary sedimentation in the basin unconformably overlying the Gombe Formation [4, 12]. 


\section{Materials and Methods}

Two lithostratigraphic sections of the Gulani Member of the Pindiga Formation outcropping around Gulani village in the Gongola Sub-basin of the Northern Benue Trough were analyzed for their facies assemblages and association. The sections were measured and described to detail stratigraphically, taking into account detailed records of thicknesses, grain sizes, sedimentary and biogenic structure and geometry. Paleocurrent measurements were also carried out on the abundant planar and trough crossbedded sandstones and the various orientations determined were used to evaluate provenance and hydrodynamic processes (e.g. [13]. The dip and strike as well as the azimuth of the crossbeds were measured using compass clinometers in this analysis, and considering that the regional dip of the beds are generally greater than $10^{0}$, tilt correction was also carried out on the values using the procedure adopted by [13].

\section{Results}

\section{Lithostratigraphic characterization}

The lithostratigraphic evaluation of the Gulani Member of the Pindiga Formation was carried out at a major outcrop in the northern and eastern part of the Gulani village, where its basal part was observed to grade transitionally into the underlying limestones and shales sequences of the Kanawa Member (Fig3a and b). The northern section conformably occurs above the eastern outcrop grading northward into the mud-plains of the Fika Shales, and these two outcrops jointly reveal great thicknesses of tens of meters thick, representative of a complete lithologic packages of the Gulani Member.

The eastern section is about $28 \mathrm{~m}$ thick and composes of coarsening upward cycles (Fig. 3a). The cycles range from $3.5-5 \mathrm{~m}$ and consist of thick trough crossbedded sandstone, occasionally associated with hummocky cross - stratified sandstones, underlain by bioturbated interbedded fine grained sandstones and claystone. The trough crossbedded sandstones are coarse grained and light brown in colour ranging in thickness from $2-2.6 \mathrm{~m}$. They are generally rich in thalassinoides burrows. The sandstones in the interbedded sands and clay are rippled or parallel laminated, while the claystones are generally light grey and mostly bioturbated. Following is an erosional gap of about $94 \mathrm{~m}$ and this is succeeded by the northern outcrop consisting of about twenty-one meters (21m) thick of sediments (Fig. 4a). This section shows fining upward cycles, composed of light grey bioturbated trough crossbedded sandstones with sharp bases overlain by thick purple to light grey bioturbated claystones. The sandstones (about $2.5-4.5 \mathrm{~m}$ thick) are generally medium grained and composed of Thalassinoides, while claystones range from $1.8-2.6 \mathrm{~m}$ thick and compose of Dimorphichnus ichnofacies. 


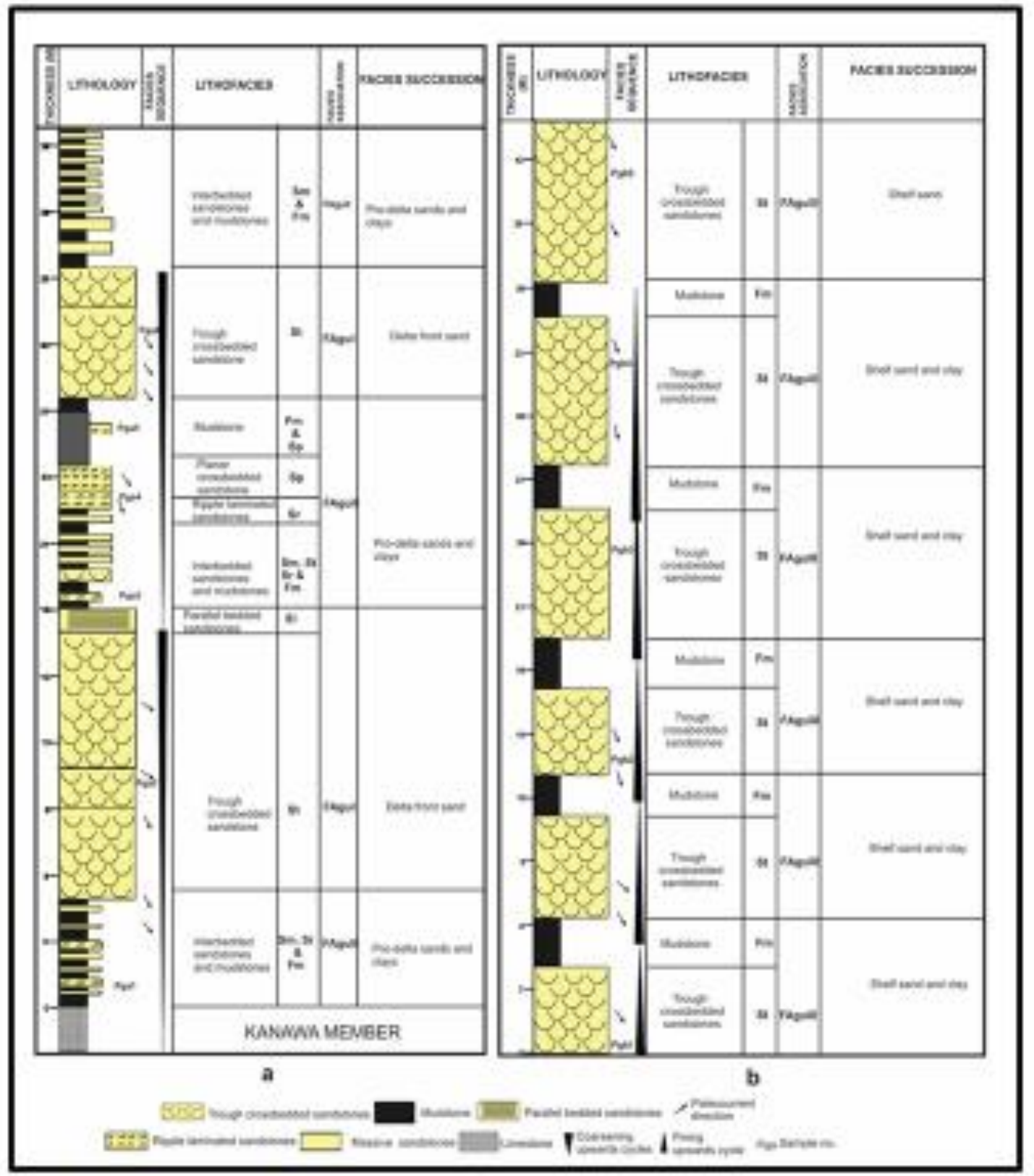

Figure 3: Lithologic section of the Gulani Member (a) Eastern part of Gulani town (b) Northern part of Gulani town.

\section{Facies analysis}

The Gulani Member is composed of five lithofacies: trough crossbedded sandstone (St), planar crossbedded sandstone $(\mathrm{Sp})$ parallel laminated sandstone (Sl), ripple laminated sandstone ( $\mathrm{Sr}$ ) and mudstone $(\mathrm{Fm})$.

Facies St: Trough crossbedded sandstone facies

The trough crossbedded sandstone facies composes of medium - very coarse grained sandstone that are dominantly poorly sorted with sub - angular to sub - rounded grains, and they range in thickness from $1.5 \mathrm{~m}-6 \mathrm{~m}$ (Fig.3a). Basal boundaries are typically erosional, and dominantly 
associated locally with mudclast and streaks. They are dominantly bioturbated with thalassinoides ichnogenera (Fig.3a). This lithofacies was interpreted to have formed from migrating sinuous 3-D dunes that stack up to generate bar forms in channel [14-17].

Facies Sp: Tabular (Planar) crossbedded sandstone facies

This lithofacies composed of fine - medium grained sandstone with sub - rounded to well-rounded grains and typically occurs above trough crossbedded sandstone facies with thicknesses in the range of $40 \mathrm{~cm}-1 \mathrm{~m}$, individual foresets ranged from $1 \mathrm{~cm}-3 \mathrm{~cm}$. they are commonly bioturbated with mud-drapes and parting occurring along corset and forest planes. This lithofacies was interpreted to have been produced from migration of 2-D dunes or sheet loading and/or interpreted as transverse bars formed under lower flow regime [17, 19].

Facies Sm: Massive sandstone facies

This lithofacies is moderately sorted with fine - medium grained sandstone that are coonly bioturbated. It ranges between $50 \mathrm{~cm}-1 \mathrm{~m}$ in thickness and commonly amalgamates to form thicker units usually overlain by trough crossbedded sandstone $(\mathrm{St})$ or parallel laminated sandstone facies (Sr) (Fig.3b). This facies is generally deposited as plane beds in lower flow regime and/or rapid sedimentation due to high deposition rates with no preservation of sedimentary structures [19]. It is commonly deposited on bars by stream floods and mostly associated with channelised flood flows around bars $[16,17]$.

Facies Sl: Parallel laminated sandstone facies

This lithofacies is generally fine grained with thicknesses of $20-70 \mathrm{~cm}$ and is commonly associated with trough crossbedded sandstone facies (St), ripple laminated sandstone facies (Sr) and mudstone facies (Fm). It is commonly bioturbated and associated with mica flakes and has sharp contacts at its basal and upper boundaries. Laminations mostly show variation in grain size or mineral composition (Fig.3c). This facies is produced by less severe or short-lived fluctuations in sedimentation conditions than those that generate beds. They result from changing depositional conditions that causes variation either in grain size, content of clay and organic material, mineral composition or microfossil content of sediments [19].

Facies Sr: Ripple laminated sandstone facies

This lithofacies is generally composes of fine - very fine grained sandstone that is well sorted with rounded grains. Thicknesses vary from $70 \mathrm{~cm}-1.2 \mathrm{~m}$ and it is mostly associated with parallel lamination (Sl) and siltstone (FmI) (Fig.3d). Asymmetrical forms are the dominant, compared to symmetrical forms and they are mostly bioturbated. This facies forms either when the water surface show little disturbance, or water waves are out of phase with bedforms during lower flow regime, or forms through migrating current ripples, under lower flow regime $[17,18]$. 

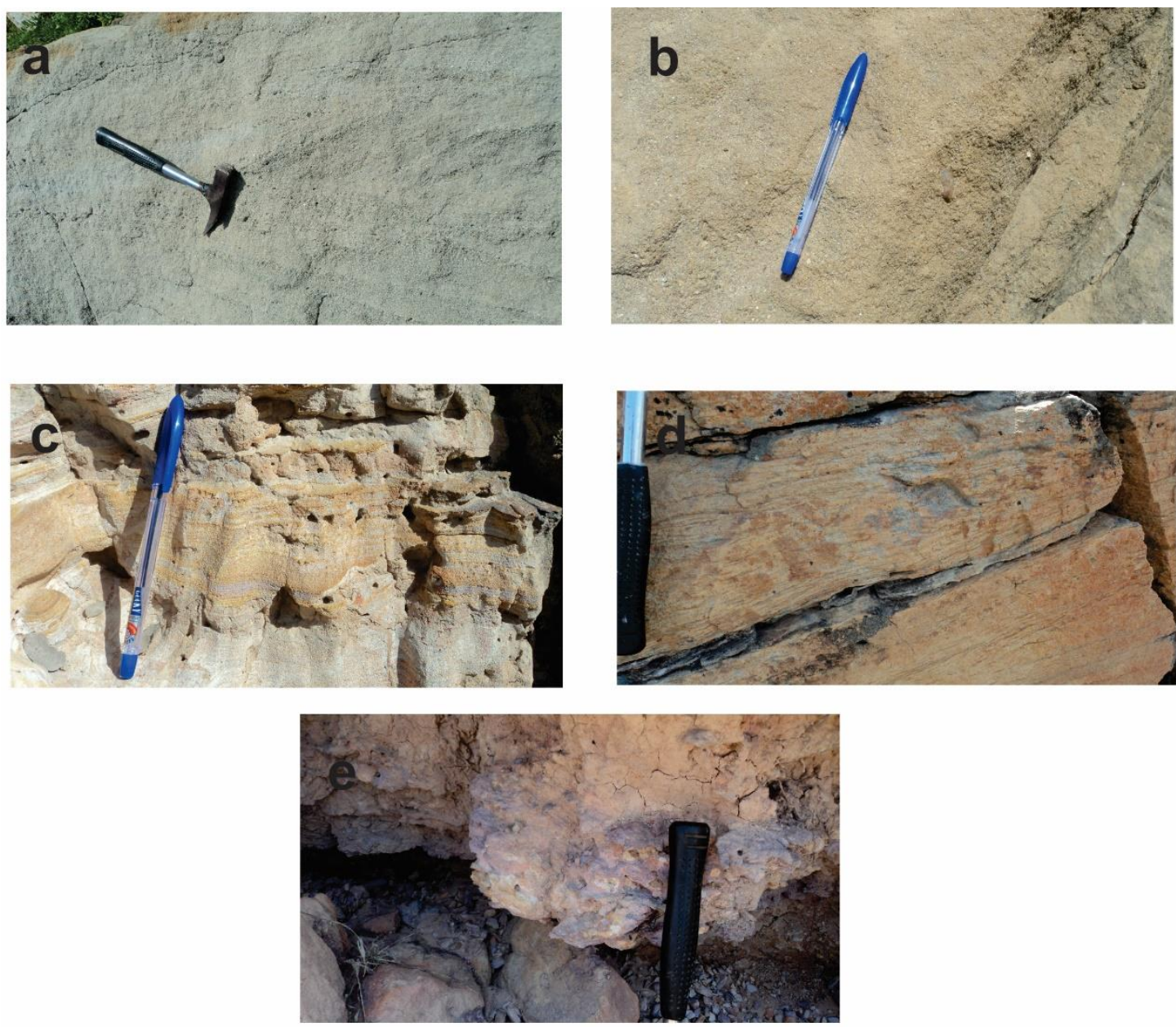

Figure 4: Showing different sections of the Gulani Member (a) Trough cross bedded sandstone (St); (b) Massive bedded sandstone (Sm); (c) Parallel laminated sandstone (SI); (d) Ripple laminated sandstone (Sr); (e) Mudstones (Fm).

Facies Fm: Mudstone facies

This lithofacies is dominantly dark grey coloured and commonly bioturbated with thicknesses ranging from $30 \mathrm{~cm}-6.5 \mathrm{~m}$. It is usually interbedded with ripple laminated sandstone facies $(\mathrm{Sr})$ and massive sandstone facies (Sm) or define the base of trough crossbedded sandstone facies (Fig. 3e). This facies forms under environmental conditions where sediments are abundant and water energy is sufficiently low to allow settling of suspended fine silt and clay. They are characteristic of marine environment where seafloor lies below the storm base, but can form in lakes and quite part of rivers, lagoons, tidal flat and deltaic environment $[15,19]$.

\section{Facies associations}

Three facies association were recognized in the Gulani Member which consist of: Delta front sands facies association (FAguI), Pro-delta facies association (FAguII) and Shelf sand and clays facies association (FAguIII) (Figs.3a and b). 
Association FAguI: Delta front sands facies association

This facies association (Figs.3a) is composed of dominantly trough crossbedded sandstone facies (St), but commonly associated with tabular (planar) crossbedded sandstone facies (Sp) and ripple laminated (Sr) and parallel bedded (SII) sandstone facies. It ranges in thickness from $4-13 \mathrm{~m}$, with trough foresets thickness of $0.5-1 \mathrm{~cm}$. It is dominantly coarse grained, poor - moderately sorted and dominantly bioturbated and contain Thalassinoides.

Association FAguII: Pro-delta facies Association

This facies association (Fig.3a) consists of interbedded sandstone and mudstone facies (Fm) with thicknesses ranging between $4-6 \mathrm{~m}$. The sandstone composes of ripple laminated sandstone facies $(\mathrm{Sr})$, parallel laminated sandstone facies $(\mathrm{Sl})$ and massive sandstone facies $(\mathrm{Sm})$. The thickness of the sandstone facies range from $15-50 \mathrm{~cm}$, while the mudstone facies $(\mathrm{Fm})$ are between $20-70 \mathrm{~cm}$ and are severely bioturbated and contain abundant Thalassinoides.

Association FAguIII: Shelf sands and clay facies association

This facies association (Fig.3b) was observed at the northern section of the Gulani village and is composed of sandstone facies overlain by mudstone facies (Fm) giving a fining upward trend. The sandstone facies range in thickness from $4-7 \mathrm{~m}$ and is severely bioturbated with abundant Thalassinoides and consists of medium grained, moderately sorted trough crossbedded sandstone facies (St) with sharp basal contacts. The mudstone facies (Fm) is generally bioturbated with Dimorphichnus ichnofauna and thicknesses of $2-3 \mathrm{~m}$.

\section{Discussion}

Lithostratigraphically, the eastern and northern outcrops of the Gulani Member at Gulani village represents a continuum lithologic succession with the eastern stratigraphic units conformably underlying the shales and limestone sequences of the Kanawa Member, grading upwards into the northern stratigraphic units (Fig 3a and b). The lower part of the Gulani Member is characterized by two distinct assemblages consisting of bioturbated heterolithic units with interbeds of fine grained ripple - parallel laminated sandstone and mudstone. This moves upward into successions of bioturbated medium-coarse grained sandstone with generally trough crossbeds, locally intercalated with massive beds and thin heterolithic units (Fig 3a). The superposed younger lithologic units on this succession at the northern part of the Gulani village are composed of interbedded amalgamated buildup of bioturbated medium grained trough crossbedded sandstone and mudstones (Fig 3b).

The facies sequences and association of the Gulani Member of the Pindiga Formation tends to indicate that it was probably deposited under deltaic and shallow marine settings. At the section east of Gulani village (Fig.3a), the facies association of the Gulani Member gave rise to typical coarsening upwards cycles consisting of interbeds of fine grained sandstones coarsening upwards to coarse grained sandstones infested with thalassnoides burrows. These bioturbated interbeds of mudstones and fine grained sandstones that are either ripple laminated or parallel laminated may probably suggest delta slope sands and clay, while the thalassinoides burrowed coarse grained trough crossbedded sandstone may suggest delta front sands [20]. The coarse grained nature of the trough crossbedded sandstones is unique only to the Gulani Member and this may have developed during sea level fall, because under such conditions fluvial activities will prevail leading to the 
deposition of coarse materials and thus case has been documented by [21]. Considering this, it may be suggested that the deltaic environment established for the Gulani Member of the Pindiga Formation most have been a fluvial dominated delta [22].

Considering the facies model of shallow marine environment of [21], established on the basis of variation of terrigeneous sediment influx and changes in hydrodynamic regimes, it may be suggested that the interbeds of thalassinoides borrowed sandstones and bioturbated claystones having dimorphichnus ichnofacies observe northern part of Gulani village (Fig.3b) may indicate shallow marine shelf having high terrigineous input of sands and clays of probably low energy hydrodynamic conditions. Furthermore, the dimorphichnus ichnofacies are usually typical of deep marine environment and their occurrence in these sediments together with high level of bioturbation may further support the earlier interpretation.

Epicontinental seas are generally partly enclosed in which the aerial extent is not large enough to initiate high energy waves or tides Einsele [21], the ancient sea way of the Benue Trough resembles this setting because it is bounded by the Basement Complex to its east and west. Hence, the reflection of the low energy condition, typified by the low energy facies identified in the section studied.

\section{Conclusion}

The regressive sandstones of the Gulani Member of the Pindiga Formation stratigraphically composes of three lithologic successions consisting of a lower portion formed of bioturbated heterolithic units with interbeds of fine grained sandstones and mudstones, a middle part with bioturbated medium -coarse grained trough crossbedded sandstone locally associated with massive beds, and a upper part constituting of bioturbated medium grained trough crossbedded sandstone and mudstones interbeds. Facies and facies association from analyses of these lithology units indicated that the Gulani Member developed from deltaic and shelf depositional processes.

\section{References}

[1] Zaborski, P., Ugodulunwa, F., Idornigie, A., Nnabo, P. \& Ibe, K. (1997). Stratigraphy, Structure of the Cretaceous Gongola Basin, Northeastern Nigeria. Bulletin Centre Researches Production Elf Aquitatine, 22: $153-185$.

[2] Carter, J. D., Barber, W., Tait E. A \& Jones, G. P. (1963). The geology of parts of Adamawa, Bauchi and Borno provinces in north-eastern Nigeria. Bulletin of Geological Survey of Nigeria, 30: $1-99$

[3] Petters, S. W. (1982). Central West African Cretaceous - Tertiary Benthics Foraminifera and Stratigraphy. Paleontolographica Abts. Vol, 179: 1-104p.

[4] Dike, E. F. C. (1993). The Statigraphy and structure of the Kerri-Kerri Basin Northeastern Nigeria. Journal of Mining and Geology, 29(2): 77 - 93.

[5] Nwajide, C. S. (2013). Geology of Nigeria's sedimentary basins. Lagos, CCS Bookshop Ltd, 86p.

[6] Allix, P. (1983). Environments mesozoiques de la paritc nord-orientale du fosse de la Benue (Nigeria), stratigraphic sedimentologic, evolution goodynmique. Traraux Laboratoire Sciences terre St. Jerome Marselle, (B), 21: 1 - 200.

[7] Guiraud. M. (1990). Tectono-sedimenatry framework of the Early Cretaceous continental Bima Formation (Upper Benue Trough N.E. Nigeria). Journal of African Earth Sciences, 10: 341 - 353. 
[8] Shettima, B., Abubakar, M.B., Kuku, A. and Haruna, A.I., (2018). Facies Analysis, Depositional Environments and Paleoclimate of the Cretaceous Bima Formation in the Gongola Sub - Basin, Northern Benue Trough, NE Nigeria. Journal of African Earth Sciences, 137, 193-207.

[9] Lawal, O. \& Moullade, M. (1986). Palynological biostratigraphy of Cretaceous sediments in the Upper Benue Basin N.E. Nigeria. Revenue Micropaleotologie, 29: 61 - 83.

[10] Abubakar, M. B. (2006). Biostratigraphy, paleoenvironment and organic geochemistry of the Cretaceous sequences of the Gongola Basin, Upper Benue Trough, Nigeria. Unpublished doctoral dissertation, Abubakar Tafawa Balewa University, Bauchi, Nigeria, 294p.

[11] Popoff, M., Wiedmann, J. \& De Klazz, I. (1986). The Upper Cretaceous Gongila and Pindiga Formations, Northeastern Nigeria. Subdivisions, age stratigraphic correlations and paleogeographic implications. Ecologea Geol. Helv., 79: 343 - 363.

[12] Adegoke, O. S., Agumanu, A. E., Benkhelil, J. \& Ajayi, P. O. (1986). New stratigraphic sedimentaologic and structural data on the Kerri-Kerri Formation, Bauchi and Borno States, Nigeria. Journal of African Earth Sciences, 5: 249 - 277.

[13] Hobbs, B.E., Means, D.W., and William, F.P., 1976. An outline of structural geology: John Wiley and Sons, New York, 384p.

[14] Plint, A. G. (2010). Wave and storm dominated shoreline and shallow marine systems. In R. W. Dalrymple \& N. P. James (Eds.); Facies model vol 8 (pp 167 - 199). St Johns, Newfoundland, Canadian Geological Association Publication.

[15] Boggs, S. Jr. (1995). Principle of Sedimentology and Stratigraphy. New Jersey, Prentice Hall, 109p.

[16] Miall, A. D. (1978). Lithofacies types and vertical profile models of braided river deposits, a summary. In A. D. Miall (Eds.); Fluvial Sedimentology vol 5 (pp 597 - 604). St Johns, Newfoundland, Canadian Society of Petroleum Geologists Publication.

[17] Miall, A.D., 2010. Alluvial deposits. In: James, N.P., Dalrymple, R.W. (Eds.), Facies Models 4. Geological Association of Canada, St. John's, Newfoundland, pp. 105 e137. GEO text 6.

[18] Miall, A. D. (1996). The Geology of Fluvial Deposits. Berlin, Springer-Verlag, 582p.

[19] Tucker, M. E. (2003). Sedimentary Rocks in the field. West Sussex, John Wiley \& Sons Ltd, 83 $158 \mathrm{p}$.

[20] Ronald, L. M. (2016). Sequence stratigraphy of fl uvially-dominated strata of the Mid-Late Pennsylvanian Conemaugh Formation, Central Appalachian BasinSequence stratigraphy of fl uvially-dominated strata of the Mid-Late Pennsylvanian Conemaugh Formation, Central Appalachian Basin. International Journal of Coal Geology 154 -155:136 -154.

[21] Einsele, G. (2000). Sedimentary Basins, Evolution, Facies and Sediment Budget. Berlin, Springer - Verlag, 267p.

[22] Rory, D. Gert, J. W. and Pantelis, K. (2015). High-resolution sequence stratigraphy of fluviodeltaic systems:Prospects of system-wide chronostratigraphic correlation. Earth and Planetary Science Letters, 412: 10-17.

\footnotetext{
*Corresponding author.

E-mail address: bukarmohammed2@yahoo.com
} 